\title{
(KLÍČOVÉ) KOMPETENCE V ČESKÉM VZDĚLÁVÁNİ: PROČ SI NAVZÁJEM NEROZUMÍME?
}

\author{
(KEY) COMPETENCES \\ IN CZECH EDUCATION: WHY DON'T \\ WE UNDERSTAND EACH OTHER?
}

TEREZA ČEŠKOVÁ

\begin{abstract}
Abstrakt
$V$ českém prostredí jsou kličové kompetence jednim z blavnich ciliu vaděláváni již od roku 2007, stále se

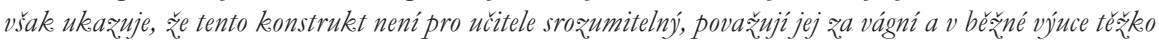
uchopitelný. Cúlem této studie je analyzovat teoretická východiska (kličových) kompetencí v zákeladním vzdèláváni a poukázat na to, že jejich chápáni se v čase promènuje, a od kurikulárního vymežni se tak. postupně odchyluje. Nejprve je popsán vývoj kompetenci a to, jake se do českébo kurikula vlastně dostaly. Následně jsou vymez̧ena dvě (resp. tři) základni pojetí kompetenci - ve smyslu normativním, holistickém (angl. competence) a ve smyslu funkéním, mèritelném (angl. competency) - a dále je popsáno, jak se tato pojetí projevují v české vąèlávací realitě. Prezentovaná studie ukazuje také na rozdíly mezi deklarovaným vymezenim kompetencí v kurikulárnich dokumentech a tím, kam se žrejmě vlivem potřeb decizni sféry posouvá. Popsaná konceptuálni i terminologická rozpolcenost a nekonzistentnost mưže být jednou z prición chybějicího blubšího teoreticky fundovanébo a empiricky ukotvenébo zkoumání, jehož duisledkem mưže být nedostatečné pochopení, a tedy i príjeti konceptu odbornou veréjností, věetně samotných učitelü.
\end{abstract}

Klíčová slova

kompetence, RVP ZV, kurikulum

Abstract
In the Czech Republic, key competences have been one of the main goals of education since 2007. However,
this construct is still not comprehensible for teachers. They consider it vague and difficult to grasp in everyday
teaching. This study aims to analyze the theoretical basis of (key) competences in primary education andpoint
out that their understanding changes over time and gradually deviates from the Czech curricular definition.
First, the article describes the development of competences and how they got into the Czech curriculum.
Two basic concepts of competences are then defined- the normative, holistic competence, and the functional,
measurable competence, and how both manifest themselves in the Czech educational reality is described.
The presented study also shows differences between the declared definition of competences in curricular documents 
and where they are probably moving due to the needs of the decision-making sphere. The described conceptual and terminological rift and inconsistency may be one reason for the lack of deeper theoretically and empirically grounded research, which may result in insufficient understanding and acceptance of the concept by the community and teachers themselves.

\section{Keywords}

competence, competency, Framework Educational Programme for Basic Education, curriculum

Odklon od dominantního zaměření na rozvíjení znalostí ve výuce na úkor všestrannějšího rozvoje žáků skrze jejich klíčové kompetence je jedním ze znaků nové kultury vyučování a učení (Janík et al., 2013), která se odráží i v základních idejích a podobě RVP ZV. Orientace na kompetence je také považována za prvek kvalitní výuky (Helmke, 2009). V českém prostředí jsou klíčové kompetence jedním z hlavních cílů vzdělávání již od roku 2007, stále se však ukazuje, že tento konstrukt není pro učitele srozumitelný, považují jej za vágní a v běžné výuce těžko uchopitelný (srov. ČŠI, 2018). K rozvíjení kompetencí ve výuce tudíž př́liš nedochází (viz např. Jarníková \& Tupý, 2011; Knecht, 2014; Lokajičková, 2014) nebo ne př́lišs efektivně (srov. Češková, 2020b).

V této studii ${ }^{1}$ se pokusím analyzovat teoretická východiska (klíčových) kompetencí v základním vzdělávání a poukázat na to, že jejich chápání se $\mathrm{v}$ čase proměnuje, a od kurikulárního vymezení se tak postupně odchyluje. Otázka pregnantnosti jejich vymezení, tedy to, co vlastně znamenají a jak je tudíž lze ve výuce potenciálně rozvíjet, se zdá být zásadní pro všechny aktéry vzdělávacího procesu. Pakliže se totiž na jejich základním vymezení neshodne výzkumná a decizní sféra, je nasnadě, že se problém přenese (ba znásobí) do učitelské praxe.

Už to, že angličtina má pro to, co nazýváme kompetencemi, dva pojmy competence a competency - naznačuje, že $\mathrm{v}$ češtině dochází ke zjednodušení či zkreslení významu. Anglické termíny jsou často vnímány jako téměř ekvivalentní. Výsledek tohoto mého bádání ale ukáže na podstatně větší rozdíly, jež se odrážejí v odlišném chápání pojmu kompetence a s ním spojeným „zmatením jazykư‘. Tyto rozdíly mohou stát i za tím, že nejsou výzkumnou ani učitelskou odbornou veřejností přijímány kladně, ačkoliv mnozí aktéři patrně podvědomě cítí, že kompetence mohou do vzdělávání, do té doby převážně orientovaného na pamětní reprodukci, vnést i pozitivní trend.

První kapitola se tedy snaží uspořádat a představit, co se skrývá pod jednotným (a tudíž matoucím) českým označením kompetence.

Studie je upravenou verzí části nepublikované dizertační práce autorky. 


\section{Historie (klíčových) kompetencí ve vzdělávacím kontextu}

Pojem kompetence se ve vzdělávacím kontextu dostal do hry v 60. letech 20. stol. jako jeden z vedlejších efektů studené války. Vypuštění Sputniku 1 na oběžnou dráhu Země Sověty způsobilo v USA šok a poptávku po změně v tom, o co Američané svoji dosavadní domnělou technologickou převahu opírali - ve vzdělávání (Hodge, 2007). V důsledku tohoto šly do vzdělávání obrovské finanční částky - byly masivně podporovány různé experimentální programy, které měly garantovat jeho lepší výsledky, od té doby produktově orientované. Změnilo se rovněž vzdělávání učitelů ${ }^{2}$, došlo $\mathrm{k}$ proměně projektovaných i implementovaných kurikul (Elam, 1971). Ve vzdělávání učitelů se tak prosadil směr competency-based (někdy též outcome-based) teacher training, jehož základem jsou kompetence pojímané jako vědomosti, dovednosti a chování (behaviors). Kompetence se tak dostaly do popředí zájmu, podporovány vládní koncepcí a výzkumem American Association of Colleges for Teacher Education a McBer Consultancy, která se zabývala výzkumem efektivnosti učitelů (srov. Manley \& Garbett, 2000). Vzdělávání založené na rozvíjení kompetencí využívala i armáda, jež na něm založila psychologický a osobnostní výcvik vojáků. V rámci této iniciativy svedla dohromady mnohé významné osobnosti z pedagogiky a psychologie, mezi něž např̀ patřili Robert Glaser, Robert Gagné, Bob Miller ad., což vedlo k podpoře výzkumu v oblasti vzdělávání založeného na rozvíjení kompetencí (Hodge, 2007). Motivace ve zlepšení profesní př́pravy, a tudíž i zlepšení ekonomických ukazatelů, vedla k obdobným snahám ústícím v definování kompetencí také ve Velké Británii skrze National Council for Vocational Qualifications (viz např. Eraut, 2002) a v Německu (Roth, 1971 in Klieme et al., 2008), kde zřejmě jako první v Evropě uvedl Dieter Mertens kompetence (tzv. Schlüsselqualifikationen) jako prvky nadřazené vzdělávacím cílům, které mají být prostředkem $\mathrm{k}$ zefektivnění odborného vzdělávání a zlepšení možností mladých lidí rychle se adaptovat na změny trhu práce (Mertens, 1974).

Zároveň od 80 . let 20. století vzrůstala poptávka po souměřitelných výstupech vzdělávání a po studiích, které by ukazovaly na jejich klíčové determinanty a vyčíslovaly ekonomické dopady souvisejících proměnných (Rychen, 2001). Jednou z odpovědí byl projekt OECD Definition and Selection of Competencies (dále DeSeCo). Ten byl úzce provázán s šetřením PISA a jeho hlavním cílem bylo na základě normativních, konceptuálních a teoretických východisek identifikovat základní - klíčové - kompetence, které

2 začaly se mj. používat videonahrávky 
jedinec potřebuje rozvíjet, aby obstál v současném světě (Rychen \& Salganik, 2001), a pomoci tak mezinárodnímu šetření měřicímu kompetenční úrovně mladých a dospělých lidí (Rychen \& Salganik, 2001). Na prosazení klíčových kompetencí v EU měla zásadní (nikoliv však iniciační) vliv Eurydice Study on Key Competencies (2002) a později doporučení vydaná Evropskou komisí či Evropským parlamentem (např. Recommendation of the European Parliament and of the Council on Key Competences for Lifelong Learning, 2006). Tyto dokumenty uvažují o kompetencích jako o prostř̌edku k ekonomickému růstu, snížení nezaměstnanosti a $\mathrm{k}$ posílení sociální koheze.

České kurikulum bylo v rámci evropských zemí jedno z prvních, do něhož se klíčové kompetence prosadily (viz Gordon et al., 2009). První zmínka (o tzv. klíčových dovednostech) se objevila dokonce již ve Strategické studii odbornébo vždéláváni a prípravy v roce $1991{ }^{3} \mathrm{~V}$ základním školství pak ve svém zaměření na kompetence ještě coby kandidátská země Evropské unie do jisté míry předběhla evropská doporučení a navzdory tehdy poměrně nedávnému zavedení nových vzdělávacích programů (Obecná škola, Zákeladni škola a Národní škola) byla na přelomu století připravována další změna - přechod na dvoustupňové ${ }^{4}$ kurikulum, jež ohled na kompetence zahrnovala. Jejich zařazení do všech stupňủ vzdělávacího systému předznamenala vedle dalších dokumentů (podrobněji viz Tupý, 2018) Koncepce vżdèláváni a rozvoje vzdèlávací soustavy v České republice (MŠMT, 1999), kde se píše o zavedení klíčových kompetencí, jež jsou „,nezbytné pro plnohodnotný život ve společnosti i v zaměstnání a pro další rozvoj osobnosti“" na což navazuje Bílá kniha (MŠMT, 2001, s. 38), která zmiňuje „vzájemnou provázanost mezi cíli, obsahem vzdělávání a kompetencemi“ a deklaruje, že „důraz bude kladen na získání klíčových kompetencí". Tato vize se naplnila s uzákoněním rámcových vzdělávacích programů 5 a klíčové kompetence se coby protiváha encyklopedických znalostí staly jedním ze základních cílů našeho vzdělávání.

Vývoj pojetí kompetencí v dokumentech klíčových pro české kurikulární vymezení klíčových kompetencí v základním vzdělávání ukazuje následující přehled (tabulka 1).

Viz http://www.nuov.cz/k-vyvoji-konceptu-kk; dále rozprac. In Kofroňová (1998).

Původním záměrem bylo vícestupňové kurikulum - Národní program vzdělávání, Rámcový vzdělávací program a školní vzdělávací programy. K rozpracování národní úrovně ale nakonec nedošlo (z osobní korespondence s J. Tupým).

5 Pro základní vzdělávání viz RVP ZV (2005) a jeho následné revize, o vývoji viz dále Tupého (2018) 


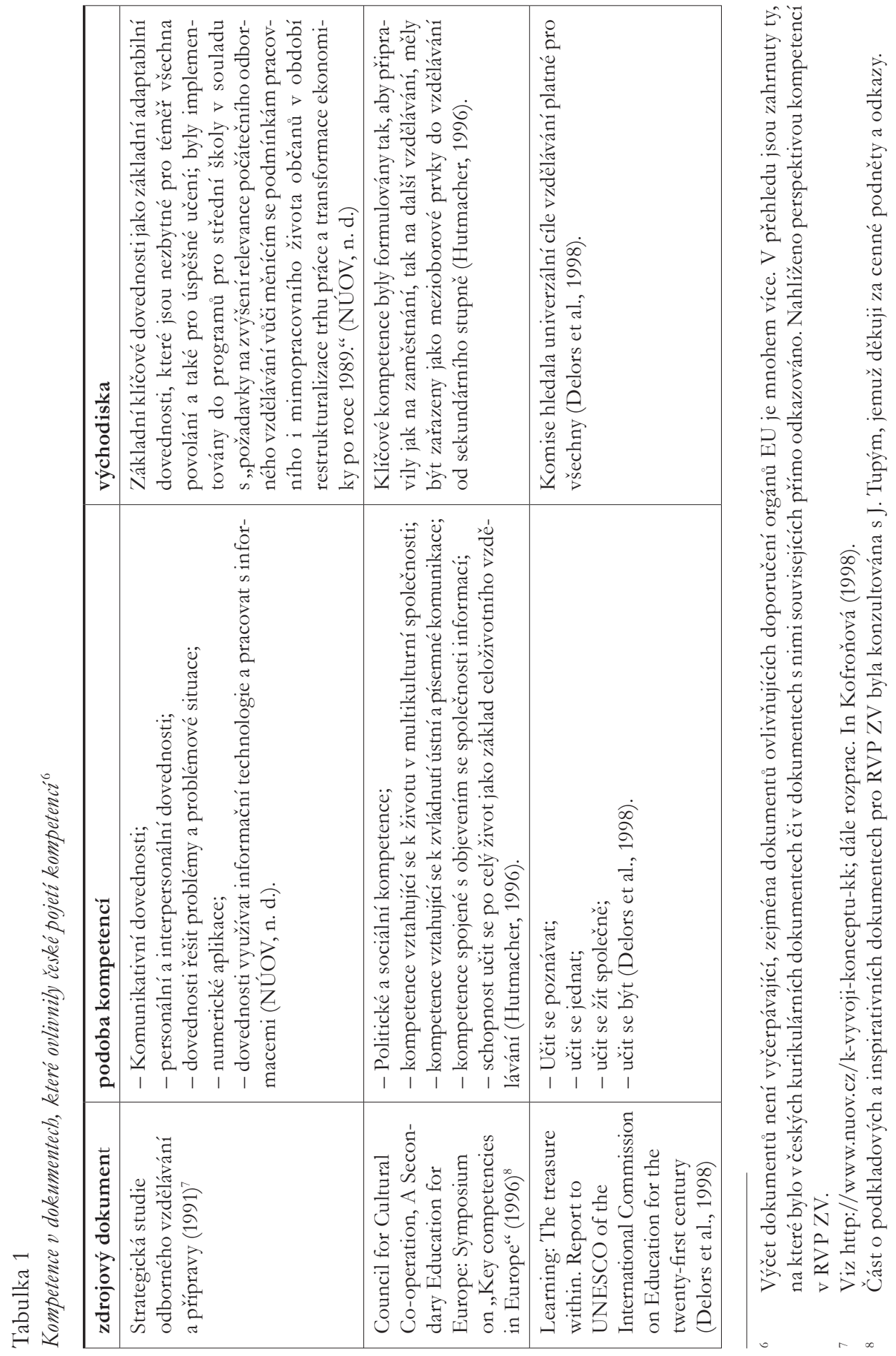




\begin{tabular}{|c|c|c|c|c|}
\hline & 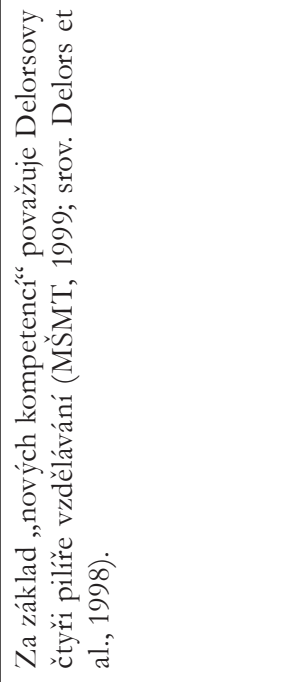 & 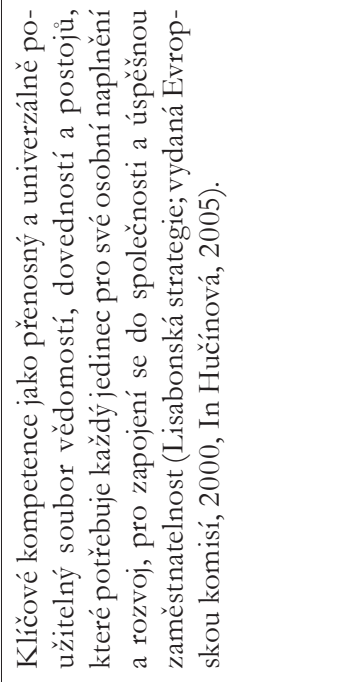 & 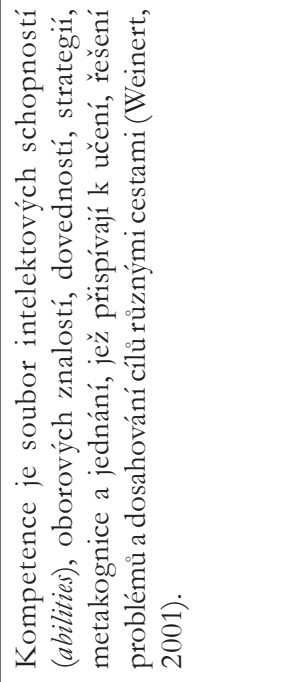 & 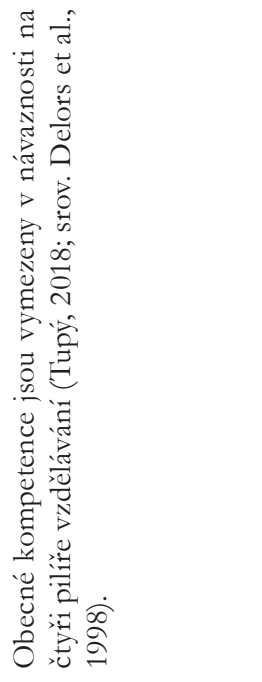 \\
\hline & 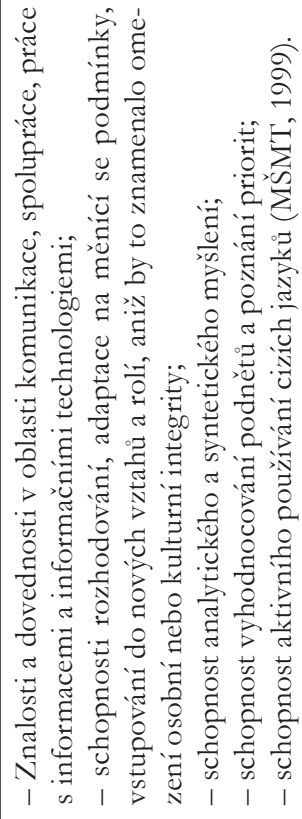 & 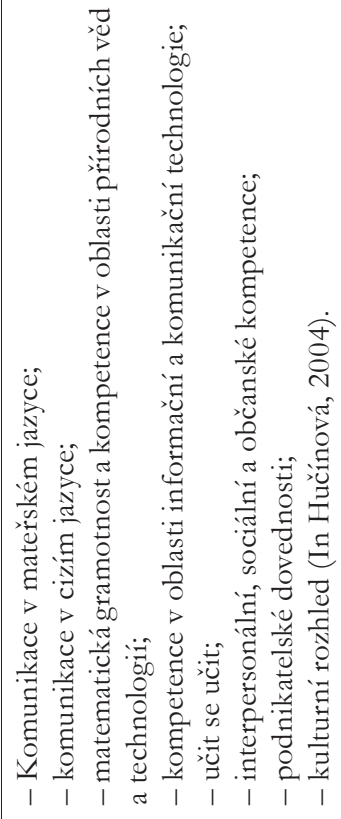 & 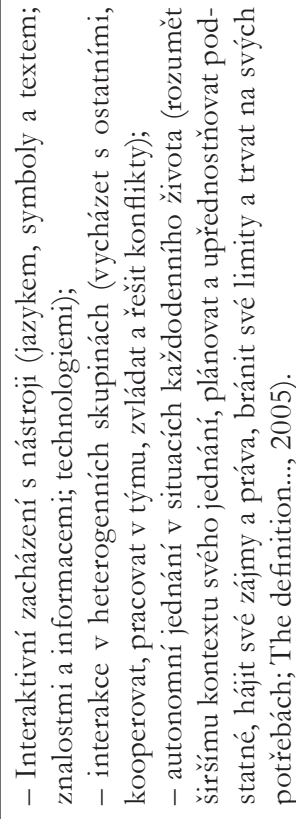 & 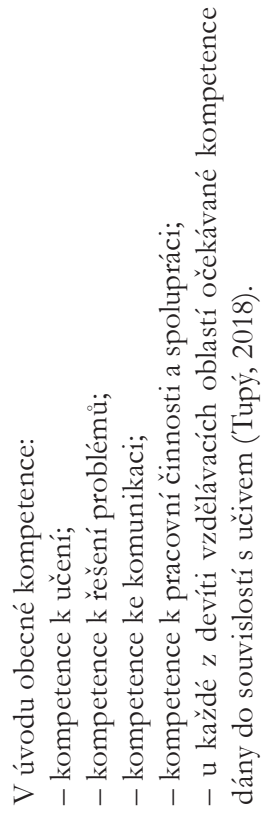 \\
\hline 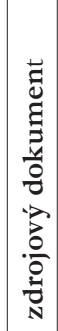 & 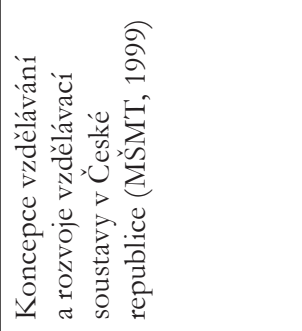 & 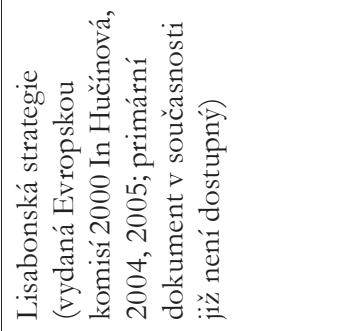 & 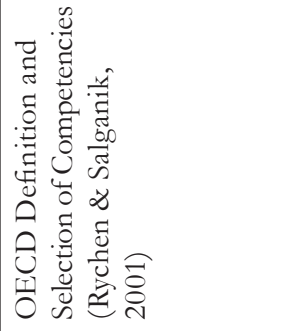 & 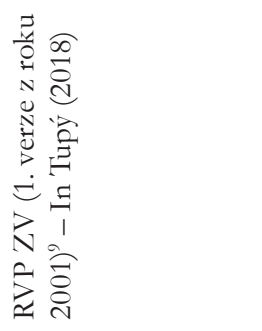 \\
\hline
\end{tabular}




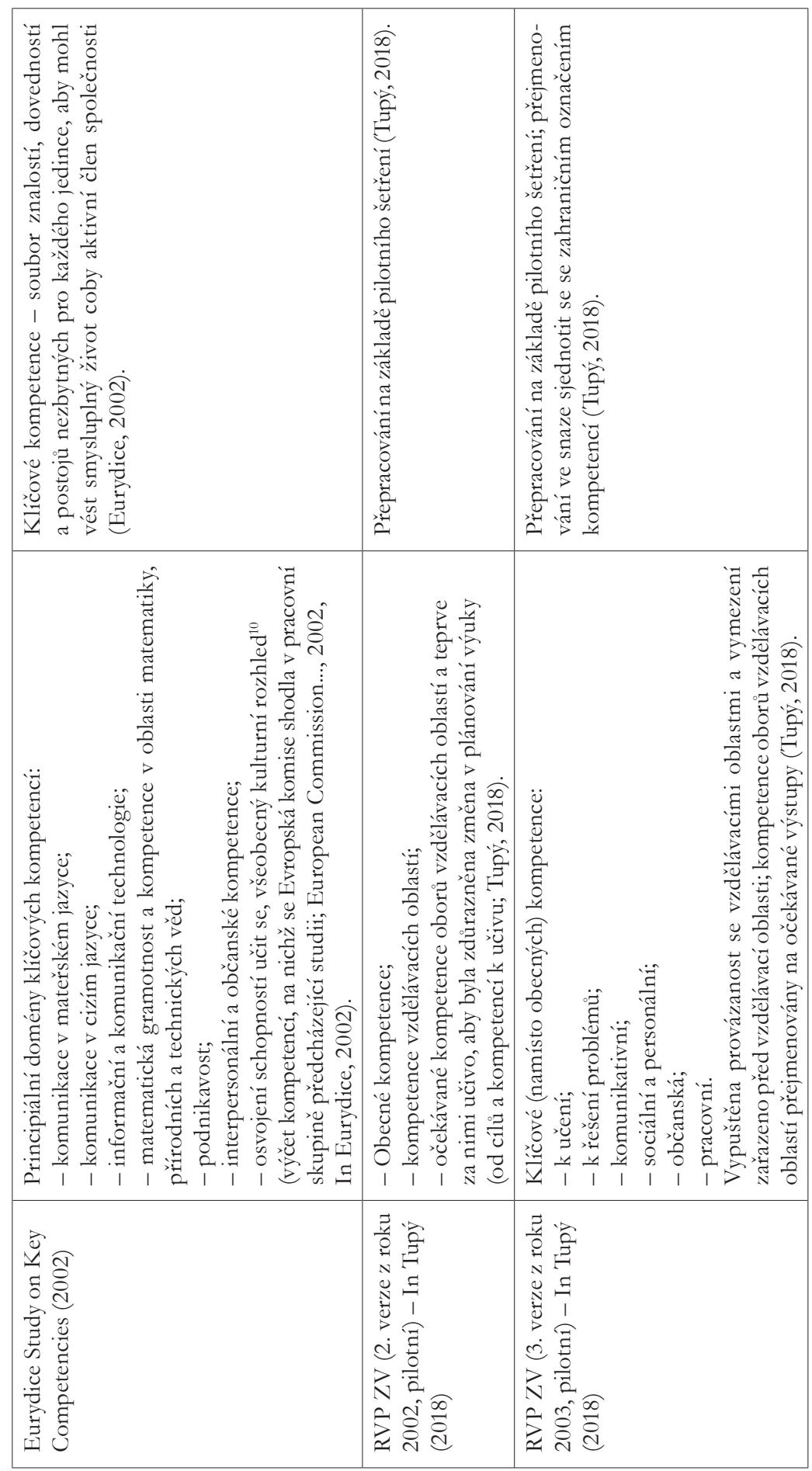




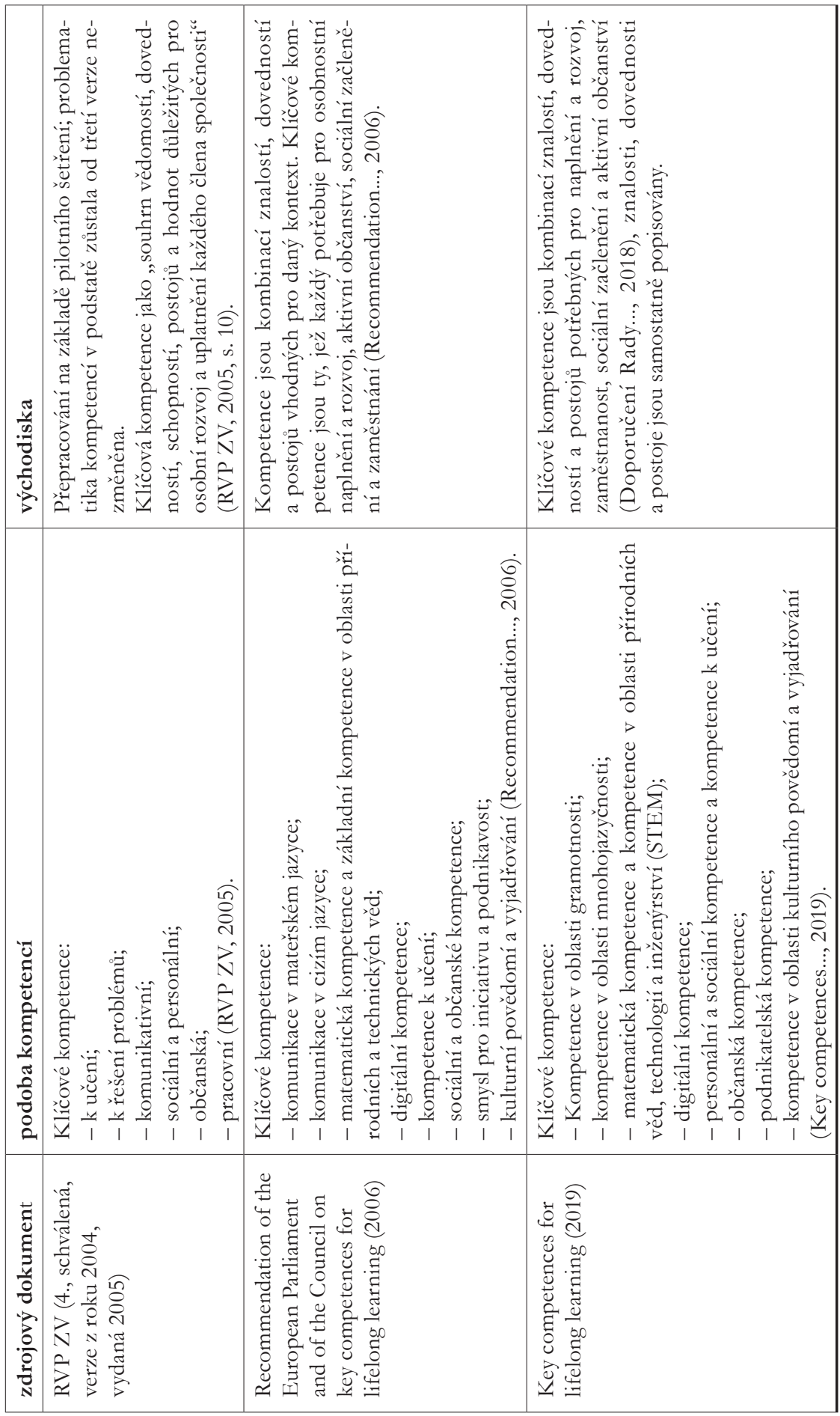


Mủžeme tedy shrnout, že v pozadí snah o zlepšení vzdělávání skrze orientace na kompetence stojí deklarované snahy pozvednout ekonomiku - a to jak v USA, tak v evropských zemích. Z iniciačních dokumentů je také patrné, že jde o pojem s původem $\mathrm{v}$ odborném vzdělávání (o tom více níže). Jejich zavedení souvisí s potřebou překonat encyklopedičnost vzdělávání ve prospěch obecněji formulovaných kompetencí, jejichž rozvoj měl napomoci $\mathrm{k}$ lepši uplatnitelnosti jedince ve společnosti a na pracovním trhu. Naše vzdělávání $\mathrm{v}$ tomto ohledu, dá se říct, předběhlo vývoj v Evropské unii a inspirováno Delorsovými čtyřmi pilíríi a klíčovými dovednostmi vymezenými pro středoškolské kurikulum formulovalo kompetence jako cílovou, mezioborovou kategorii vzdělávání.

$\mathrm{V}$ tabulce můžeme pozorovat posuny v chápání kompetencí, které se odehrály mezi jednotlivými verzemi RVP ZV. Jejich nastavení, a zejména doménová (ne)specifičnost, se v průběhu značně měnily. V první verzi RVP ZV šlo sice o kompetence nadoborové, ty ale byly dány do souvislostí s učivem jednotlivých vzdělávacích oblastí. Ve druhé verzi byly vzdělávací oblasti upozaděny ve snaze upozornit na to, že je třeba ve výuce kompetence rozvíjet cíleně, ne jako přívažek $\mathrm{k}$ učivu. Ve třetí verzi pak byla provázanost s jednotlivými doménami vypuštěna zcela, stejně jako $\mathrm{v}$ aktuálně platné verzi RVP ZV, a kompetence by tak měly být rozvíjeny např́č všemi vzdělávacími oblastmi (byt' v některých oblastech se samožrejmě některé kompetence rozvíjejí snáz).

Převažuje jeho normativní chápání, tedy pojetí kompetence jako cílové kategorie vzdělávání (srov. Klieme et al., 2008). Ze Strategického rámce ČR 2030... (2017) vyplývá, že orientace na kompetence bude hlavním cílem vzdělávání i nadále. V aktuálních doporučeních Evropské komise (Doporučení Rady..., 2018; Key competences..., 2019) ale kompetence v podstatě korespondují se stávajícím vymezením vzdělávacích oblastí v RVP ZV, což se zdá být odklonem od jejich obecného mezioborového pojetí a př́klonem k pojetí oborovému (domain specific). Bude jistě zajímavé sledovat, jaká východiska zvolí v současnosti připravované revize a kam se budou ubírat. V následující kapitole nahlédnu podrobněji na to, co kompetence jsou a jak jsou provázány s obsahovými doménami. 


\section{Competence nebo competency? Pokus o rozpletení spletených paradigmat}

Pojetí, a tedy i definování klíčových ${ }^{11}$ kompetencí je nepřeberné množství (viz např. Rychen \& Salganik, 2001; či Baartman et al., 2007; Hartig et al., 2008; v českém prostředí např. Knecht, 2014; Knecht et al., 2010; Lokajíčková, 2013; Skalková, 2005; Veteška \& Tureckiová, 2008; aj.) a jejich srovnání samotné by vydalo na samostatnou práci. Už v uvedeném přehledu (tabulka 1) lze ale pozorovat nejednotnou terminologii, která se ke kompetencím váže $\mathrm{v}$ pojmech competence-competency. Může být způsobena různými iniciačními dokumenty i vývojem školských soustav, a především tradic, z nichž byla brána inspirace v jednotlivých dokumentech (srov. Skalková, 2005). Čeština do potenciálních snah o pregnantní definování vnáší další nejasnost tím, že má pro oba pojmy i přes jejich odlišný význam jednotný překlad kompetence (srov. Knecht et al., 2010). V následující tabulce se pokusím shrnout základní charakteristiky, kterými se oba pojmy odlišují. Kompetence (competence) v holistickém pojetí je pak doplněna ještě o variantu, která se od původní odštěpila (prostřední sloupec).

11 Klíčovou (v zahraniční literatuře označovaná př́idavným jménem „key/Schlüssel“, „,core“, méně často pak „basic“ či „essential“) kompetencí bývá označována kompetence, která je prospěšná jak každému jedinci, tak společnosti a musí umožňovat celoživotní učení, resp. zlepšování, které ve svém důsledku umožní „udržet krok“ s neustálým vývojem; dále aktivní občanství a začlenění (sociální kapitál) a zaměstnatelnost (European Commission..., 2004; Eurydice..., 2002; v souvislostech viz Knecht, 2014). Vzhledem k tomu, že jde spíše o deklaraci, která pomáhá najít „důležitějšíi kompetence, mezi něž ale všechny kompetence jmenované v RVP ZV patří, budu dále pro zjednodušení používat pro klíčové kompetence pouze výraz kompetence. 


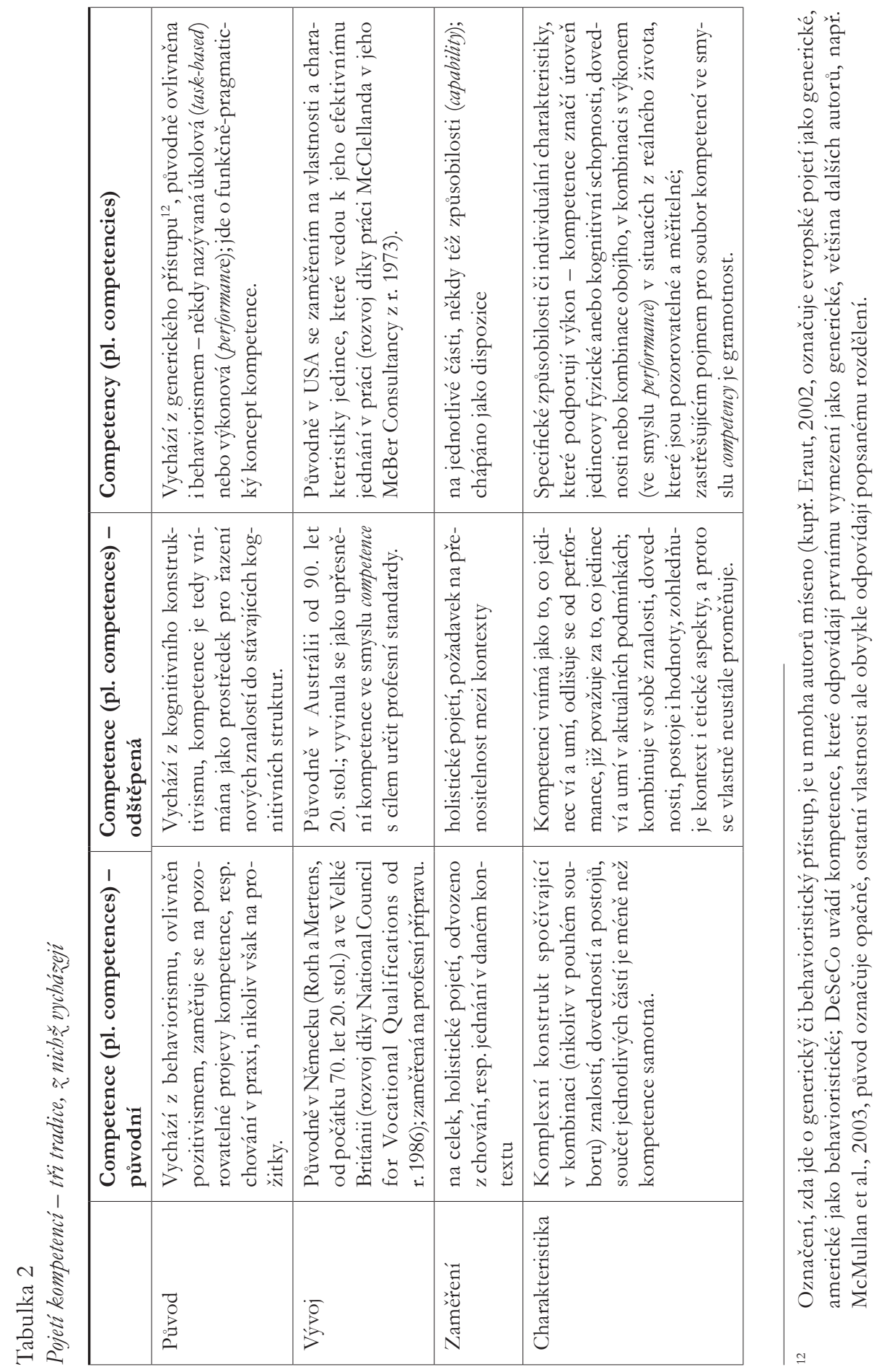




\begin{tabular}{|c|c|c|c|c|}
\hline 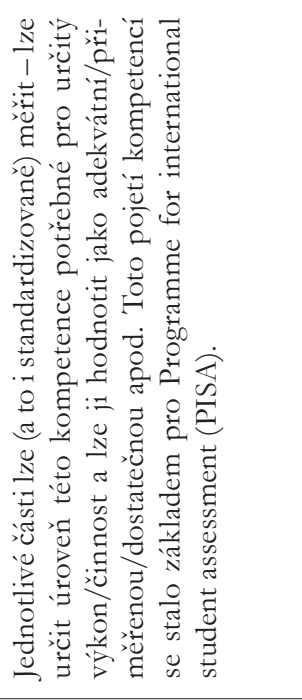 & 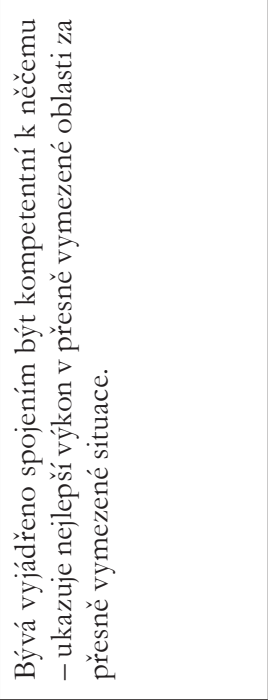 & 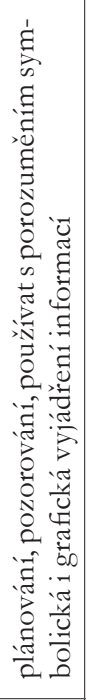 & 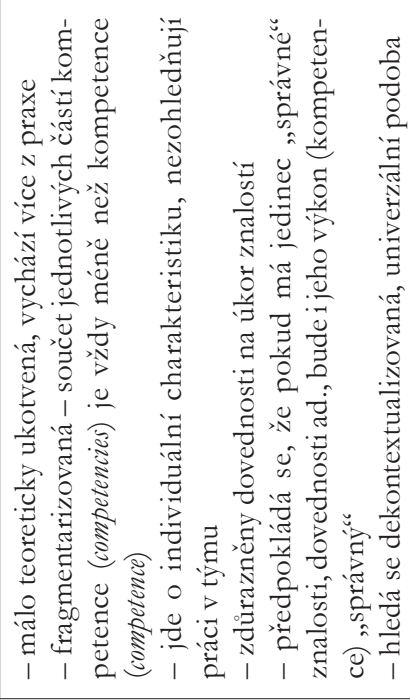 & 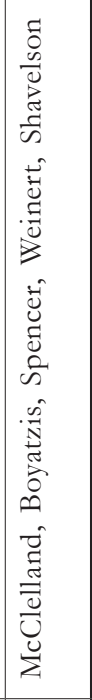 \\
\hline 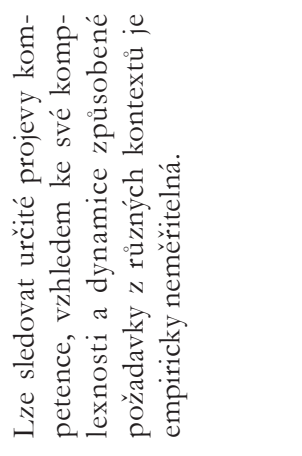 & 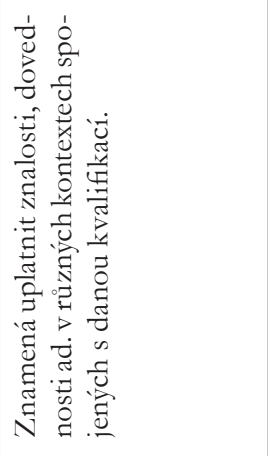 & 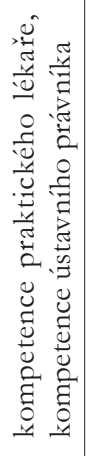 & 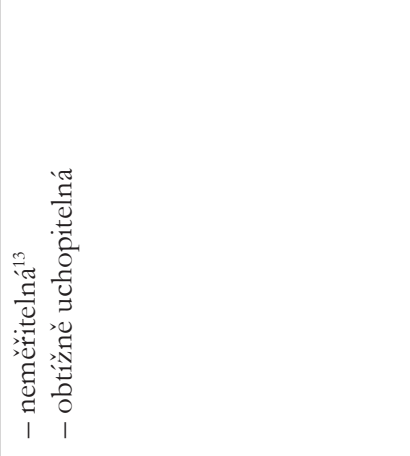 & 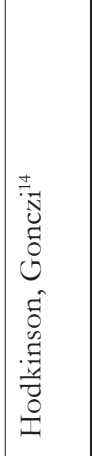 \\
\hline 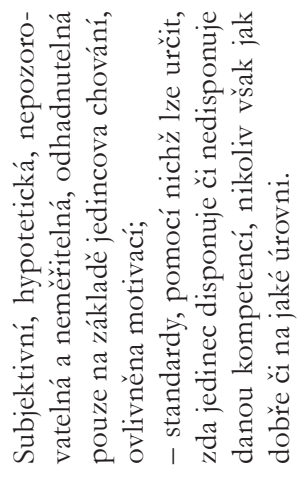 & 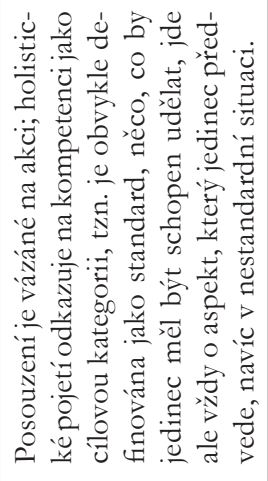 & 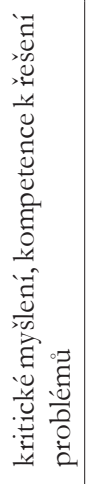 & 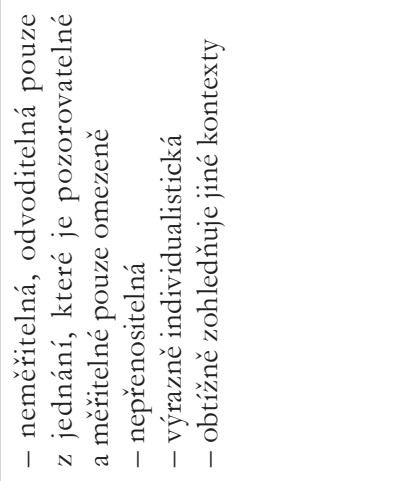 & 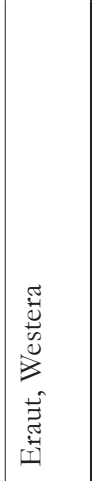 \\
\hline 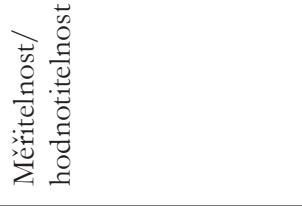 & 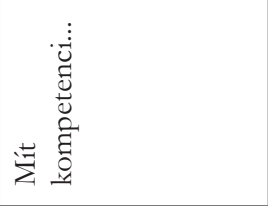 & & 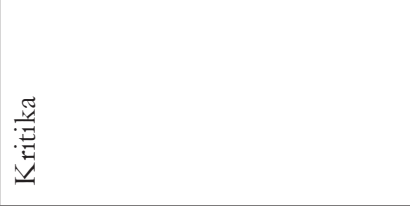 & 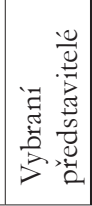 \\
\hline
\end{tabular}


Z charakteristik vyplývají dvě dominantní odlišné vývojové linie ${ }^{15}:$ (1) „evropská“" pojímající kompetenci holisticky jako minimální, standardní úroveň dovedností, znalostí a postojů, jež jedinec prokáže jen jednáním; a (2) „americká“" která je zaměřená na jednotlivé dovednosti, znalosti a schopnosti, které jsou pozorovatelné a měřitelné, a tedy hodnotitelné. Toto pojetí (ve smyslu competency) proto ve své podstatě odpovídá v českém prostředí zaužívanému pojmu gramotnost. Lze se jen dohadovat, zda nejednotnost ve vymezení kompetencí (competence vs. competency) v jednotlivých výše zmíněných dokumentech - a to i v těch vydaných stejnými institucemi - je způsobena vědomou změnou $v$ chápání daného pojmu. $V$ mnoha dokumentech je s těmito pojmy nakládáno volně, např. DeSeCo popisuje mezi pojmy jen malé rozdíly a pro obě varianty využívá týž plurál - competencies; kompetenci ve smyslu competence chápe „(a) jako koncept a jeho teoretizaci, (b) jako úroveň specifické schopnosti, dovednosti nebo kompetence (competency) (např. kompetence ve čtení nebo matematice). Kompetenci ve smyslu competency pak užívá v souvislosti s požadavkem, který jedinec je, nebo není schopen splnit (napr. kompetence připojit se a fungovat ve skupině)“. (Rychen, 2001, s. 3) PISA zase např̀ v jednom dokumentu uvádí, že PISA 2012 nabízí širší měření kompetence (problem-solving competency) než v šetření 2003, kompetenci $\mathrm{k}$ řešení problémů dále nazývá jako problem-solving competence, ale zároveň její definice je velice podobná definici kompetence (competency) z šetření 2003 (viz PISA, 2004); a o téže kompetenci v jiných dokumentech (např. PISA, 2013) i ve východiscích k PISA 2015 (PISA, 2017) hovoří jako o competency. Toto mísení obou pojmů jejich možné pregnantní definování ještě více rozostřuje, ne-li znemožňuje - a koncepční práci s nimi jen ztěžuje. Je proto otázkou, nakolik je toto rozdělování ještě validní a funkční.

13 Gonczi (1994) hodnocení připouští a navrhuje, aby se skládalo z hodnocení znalostí, řešení problémů, technických dovedností, postojů a etických aspektů.

14 Někteři autoři u tohoto typu zmiňují i Noama Chomského a jeho lingvistickou kompetenci. Tato kompetence je ale specifická svou oborovostí a založením na pravidlech (srov. Weinert, 2001).

15 Knecht (2014) popisuje ještě rozdíl v „,evropské“ linii mezi britskou větví, charakteristickou zájmem o rozlišování vědomých a nevědomých myšlenkových procesů při řešení problémů, a kontinentální větví, zaměřenou na souvislosti mezi kognitivními, motivačními a sociálními aspekty řešení problémů. 
Do všeobecného vzdělávání se kompetence dostaly ze vzdělávání odborného, v němž „být kompetentni““ $v$ dané oblasti znamená „být odborně způsobilý“. Odborné vzdělávání tak užívá kompetence ve smyslu competency a spojuje je s rozvíjením ve smyslu „training“. Kompetence v něm mají, na rozdíl od užití ve všeobecném vzdělávání, jasný význam spojený s jejím konkrétním využitím v odborné praxi, lze je hodnotit a měrit. Jejich přenesení do vzdělávání obecného je ale značně problematické, nebot' $v$ něm nelze jasně definovat konkrétní kompetence (competency), které jedinec bude potřebovat (srov. Willbergh, 2015). Proto bylo snahou nalézt kompetence obecnějǔśi, nadoborové, klíčové (competence, viz např. DeSeCo), které budou platné, bude-li jedinec směřovat $\mathrm{k}$ jakémukoliv povolání. Zaměření na dílčí kompetence (competency) tak s sebou přináší riziko redukování vzdělávání pouze na př́pravu pro pracovní trh (srov. nap̌r. Kaščák \& Pupala, 2012).

\section{Kompetence v kontextu českého základního vzdělávání aneb jak se tato nekonzistence projevuje v praxi}

Vrátíme-li se s tímto porozuměním k otázce, jak se dostaly kompetence do českého kurikula (viz tabulku 1), vidíme, že pojetí kompetencí v RVP ZV bylo inspirováno (a) Delorsovými čtyřmi pilíri (viz Delors et al., 1998) a dokumenty formulovanými pro střední a odborné vzdělávání, v nichž jsou popisované spíše jako cílová kategorie (tedy jako competence); a (b) dokumenty z evropské vzdělávací politiky, která stojí zejména na poznatcích OECD (viz Rychen \& Salganik, 2001), jejichž ukotvení je ale od počátku pojímáno jako dílčí, měřitelné části (competency), ačkoliv původní návrhy byly taktéž a to je vzhledem $\mathrm{k}$ dalšímu vývoji zajímavé - dle charakteristik míněny jako holistické (competence, viz Hutmacher, 1996; přestože už tehdy byly psány jako competency s tím, že je mezi oběma variantami „marginální rozdíl“ - viz s. 9 téhož dokumentu).

V RVP ZV jsou kompetence popsány jako ideální cílový stav pro tento stupeň vzdělávání, $\mathrm{k}$ němuž se každý žák přibližuje podle svých individuálních možností a na nějž je navazováno $\mathrm{v}$ dalších stupních. Předpokládán je celoživotní rozvoj, škola by měla poskytovat dostatek prŕležitostí pro to, aby tento rozvoj nastartovala a na dané úrovni podporovala. Vzhledem $\mathrm{k}$ tomu, že součástí kompetencí v českém kurikulu jsou i hodnoty a postoje, lze dokonce uvažovat o jejich vnímání ve smyslu kognitivně-konstruktivistickém (viz prostřední sloupec $\mathrm{v}$ tabulce 2). V anglickém překladu RVP ZV je ale navzdory tomu užíván výraz competencies, tedy plurál slova competency. To jen prohlubuje zmatení, které se s tímto pojmem v českém prostředí pojí a jež se zrcadlí i v kritice kompetencí (o tom více v diskusi). 
Funkčnímu pojetí (ve smyslu competency), tedy v podstatě vymezení kompetencí k českému kurikulu přímo protikladnému, odpovídá i tendence aktérů ovlivňujících podobu (současnou i revizní) kurikula (viz ČŠI, 2018, či aktivity $\mathrm{C}^{\mathrm{C}} \mathrm{I}^{16}$ ) kompetence porovnávat, a tedy diagnostikovat a sumativně hodnotit, ačkoliv to není teoreticky možné. ${ }^{17}$

Prvotní prezentované úvahy o revizích RVP ZV (Fidrmuc, 2018) ${ }^{18}$ navíc ukazují na pravděpodobné navázání kompetencí na vzdělávací oblasti, což se projevilo např. při zavedení digitální kompetence (RVP ZV, 2021). Ačkoliv je digitální kompetence zařazena mezi stávající kompetence, tedy holisticky vymezené, jejichž definice se oproti původní nijak nezměnila, doprovází ji výrazné navýšení časové dotace ve vzdělávací oblasti informatiky (z původních dvou na šest hodin v průběhu základního vzdělání). Vzhledem k tomu, že má jít o kompetenci nad-/mezioborovou, k jejímuž „utváření a rozvíjení musí směřovat a přispívat veškerý vzdělávací obsah i aktivity a činnosti, které ve škole probíhaji “" (RVP ZV, 2021, s. 10), je jednostranné navýšení hodin informatiky, doprovázené snížením časové dotace u jiných oblastí, resp. oborů (které jistě nepřispěje tomu, že se v nich víc bude brát ohled na kompetence), konkrétním př́íkladem nekonzistentnosti mezi tím, co je deklarováno, a tím, jak je to realizováno. I digitální kompetence, stejně jako kompetence $\mathrm{k}$ řešení problémů, sociální a personální ad., by naopak měla být rozvijena např́ić vzdělávacími oblastmi, resp. obory, přičemž - stejně jako u ostatních kompetencí - jsou některé vzdělávací oblasti pro její rozvíjení vhodnější (např. vzdělávací oblast informatika či jazyk a jazyková komunikace) a některé méně vhodné (např. vzdělávací obor tělesná výchova).

Tyto snahy jsou však v zásadě v souladu s evropským trendem, jenž úpravy původně normativně zamýšlených kompetencí (viz Hutmacher, 1996) staví zejména na základě výsledků šetření PISA (viz nap̌r. Proposal..., 2018). PISA ale sleduje kompetence ve funkčním pojetí, přičemž klíčové kompetence rozděluje na tři základní části, kdy samostatně vymezuje jednotlivé znalosti, dovednosti a postoje (viz např. Key competences..., 2019). Je evidentní, že se mísí perspektivy, a dochází tak patrně k obratu v chápání kompetencí - od celistvého ideálu $\mathrm{k}$ měritelným jednotlivostem, a to jak na české, tak evropské úrovni. Otázkou je, nakolik jde o záměr způsobený „kontaminací" ideového kurikula pracovním trhem, a nakolik pouze o důsledek nekonzistentního vymezení.

${ }_{16}$ Viz https://www.csicr.cz/Prave-menu/Projekty-ESF/Komplexni-system-hodnoceni a Analýza..., 2018).

17 Že poměřování kompetencí (competence) kvantitativní cestou prakticky není možné viz např. Harrise (2001) v souvislostí se studií DeSeCo.

18 O těchto revizích, byt' jen rámcové podobě, jsou v době psaní této studie zatím pouze kusé informace. 


\section{Diskuse a závěr}

V předložené studii jsem se zabývala (klíčovými) kompetencemi v českém kurikulu pro základní školy. Na vývoji a teoretických východiscích jsem ukázala, jak se liší jednotlivá pojetí kompetencí, s nimiž se v české vzdělávací realitě potýkáme. Tato konceptuální i terminologická rozpolcenost a nekonzistentnost může být jednou z přičin chybějícího hlubšího teoreticky fundovaného a empiricky ukotveného zkoumání, jehož důsledkem může být nedostatečné pochopení, a tedy i přijetí konceptu odbornou veřejností, potažmo učiteli samotnými. Pokud by totiž decizní sféra respektovala rozdíly mezi jednotlivými vymezeními, nemísila by oba pojmy a jasněji by definovala, co je vlastně očekáváno. Důsledkem toho by bylo mnohem snazší kompetence zkoumat (bylo by totiž jasnější, jakou jejich charakteristiku vůbec lze zkoumat), a tedy formulovat doporučení, jak kompetence ve výuce vlastně rozvíjet. To by bylo užitečné a žádoucí tím spíšs, že je rozvíjení kompetencí deklarováno jako jeden z hlavních cílů vzdělávání. Studie tak zcela konkrétně ukazuje, jak se (ne)koncepce decizní sféry promítají až do samotné edukační reality. Při pohledu touto optikou se učitelům a odborné veřejnosti nelze divit, že si s rozvíjením kompetencí ve výuce nevědí rady. Poskytování př́ležitostí $\mathrm{k}$ rozvíjení competence a competency se totiž může výrazně lišit. Ukážeme si to na př́kladu kompetence $\mathrm{k}$ řešení problémů.

Kompetence ve smyslu competence není měřitelná a přesně zachytitelná, protože jde o komplexní konstrukt, který nemůže stát sám o sobě ani být rozvíjen bez oborových obsahů (srov. Slavík et al., 2017). Štech (2009) kupř. nabádá $\mathrm{k}$ propojení učiva a kompetence, užívá $\mathrm{v}$ této souvislosti spojení figura a pozadí. Je tedy evidentní, že ve výuce nejde o to „vyučovat kompetence“, nýbrž o to upravit práci s úlohami tak, aby mírily zároveň na obsahové (kognitivní) cíle a zároveň postupně, ale ve vzdělávání soustavně (protože mj. také celoživotně) rozvíjely žákovy kompetence. To by tedy znamenalo vytvářet ve výuce obsahově (oborově) zakotvené úlohy formulované tak, že poskytují zároveň příležitost kompetence rozvíjet. Takové úlohy vycházejí z problémově orientovaného vyučování a učení (podrobněji k možnostem rozvíjení viz nap̌r. Češková, 2020a), popř. využívají prvky badatelsky orientované výuky (viz např. Papáček, 2010) či další konstruktivistické př́ístupy (viz např. Chytrý et al., 2020). Společnou mají snahu kognitivně aktivizovat žáky, a to s ohledem na reálné prostředí či jevy, s nimiž je v úlohách pracováno, a zároveň potřebu usazení nových poznatků do stávajících obsahových struktur. Vždy tedy pracují s konkrétními vzdělávacími obsahy, které pomocí vhodně formulovaných učebních úloh předkládají tak, že zároveň mají potenciál rozvíjet danou kompetenci. 
Naproti tomu kompetence ve smyslu competency lze ve výuce rozvíjet i bez konkrétního obsahu - cíleně, pomocí úloh, které jsou konstruovány př́ímo s ohledem na rozvíjení dané kompetence, resp. jejich dílčích částí. Uplatňován by tedy byl funkční model a výuka by sestávala nap̌̌r z řešení úloh využívaných v mezinárodním šetření PISA, které rozpracovává kompetenci do částí, na základě kterých pak tvoří zaměření testových úloh. Kaščák s Pupalou (2012) v tomto kontextu hovoří o tom, že by se pak ze vzdělávání stal spíše výcvik. To je sice zdánlivě jednodušší, protože učiteli poskytuje vodítka, na které konkrétní izolované jevy (u kompetence $\mathrm{k}$ řešení problémů kupř. plánování postupu řešení, vybírání podstatných informací) se zaměřit, problém ovšem je, že součet jednotlivých částí (dílčích složek - částí competency) se nerovná celku, tedy kompetenci ve smyslu competence (srov. Ford, 1992; McClelland, 1973; Sadler, 2013; Shavelson, 2010). Předpoklad, že budeme-li žáky připravovat (a testovat) na jednotlivé složky/části kompetence, získáme tím povědomí o jejich kompetenci samotné (ve smyslu competence), tedy neplatí. Přináší to s sebou také mnohem větší riziko oborové neukotvenosti či obsahové vyprázdněnosti, což jsou jedny z nejčastějších výtek kompetenčně orientované výuky (viz např. Janík et al., 2011; Kaščák \& Pupala, 2009, 2012; Štech, 2009, 2013; Willbergh, 2015), a s tím spojenou časovou limitaci, nebot' na tyto úlohy je nutné vyšetřit $\mathrm{v}$ nějakém (oborově zaměřeném) předmětu čas. „Učit se kompetence“ pak navíc popírá její původní ideje, at’ už v jakémkoliv pojetí. Proto tento způsob není pro školní výuku př́liš vhodný.

Prezentovaná studie ale ukazuje také na rozdíly mezi deklarovaným vymezením kompetencí v kurikulárních dokumentech a tím, kam se zřejmě vlivem potřeb decizní sféry posouvá. Jako by se v evropském pojetí (míněno v dokumentech EU) - stejně jako v českém revidovaném pojetí - kompetence posouvaly směrem ke gramotnostem, $\mathrm{k}$ měřitelnému pojetí - competency (ačkoliv jsou stále deklarovány jako competence). Jako by potřeba porovnávat se a mít měřitelné výsledky vzdělávání byla důležitější než rozvíjení jedince a směřování $\mathrm{k}$ ideálu, $\mathrm{k}$ němuž se snažíme celoživotně přiblížit a jenž byl ukotven $\mathrm{v}$ dosud platném kurikulu. V projektovaném kurikulu deklarujeme jedno pojetí kompetencí, ale při hodnocení se stavíme za jiné. Je řešením změnit ukotvení kompetencí v českém kurikulu? Je řešením vymezit dvojí kompetence - klíčové, které jsou nad-/mezioborové, holisticky pojaté, a k nim oborové, funkčně/ gramotnostně viděné? A neprohloubíme tím pouze ono kritizované učení se pro test?

\section{Poděkování}

Autorka děkuje dr. Tupému za cenné zdroje i podněty doprovázející vznik studie a také oběma recenzentům za výborné připomínky, které pomohly text doplnit a zkvalitnit. Vznik této studie byl podpořen projektem GAČR 20-13038S, Produktivni kultura vyučováni a učení. Autorka děkuje za podporu. 


\section{Literatura}

Baartman, L. K., Bastiaens, T. J., Kirschner, P. A., \& Van der Vleuten, C. P. (2007). Evaluating assessment quality in competence-based education: A qualitative comparison of two frameworks. Educational Research Review, 2(2), 114-129. https://doi.org/10.1016/j. edurev.2007.06.001

Češková, T. (2020a). Interakce při řešení problémově orientovaných úloh ve výuce přírodovědy. Orbis Scholae, 14(1), 49-80. https://dx.doi.org/10.14712/23363177.2020.3

Češková, T. (2020b). Když potenciálně rozvíjející situace nerozvíjí: kritické didaktické incidenty v problémově orientované výuce. Pedagogika, 70(2), 197-223. https://dx.doi. org $/ 10.14712 / 23362189.2020 .1636$

ČŠI. (2018, 23. února). Analýza zabraničnich systémù hodnocení kličových kompetencí a systému hodnocení netestovatelných dovedností se souborem doporučeni pro školni hodnoceni kličových kompetenci RVP ZV a externi hodnoceni skeolni podpory rozvíjeni klićových kompetenci RVP ZV. http://www.csicr.cz/ html/2018/Analyza_klicovych_kompetenci/html5/index.html?\&locale=CSY

Delors, J., Al Mufti, I., Amagi, I., Carneiro, R., Chung, F., Geremek, B., Gorham, W., Kornhauser, A., Manley, M., Quero, M. P., Savané, M. A., Singh, K., Stavenhagen, R., Suhr, M. W., \& Nanthao, Z. (1998). Learning: The treasure within. Report to UNESCO of the International Comission on Education for the twenty-first century. Unesco Publishing.

Doporučeni Rady ze dne 22. kvètna 2018 o kličových kompetencich pro celoživotni učeni (Text s významem pro EHP). (2018). https://eur-lex.europa.eu/legal-content/CS/TXT/PDF/?uri= CELEX:32018H0604(01)\&from $=\mathrm{EN}$

Elam, S. (1971). Performance based teacher education. What is the state of the art? American Association of Colleges for Teacher Education.

Eraut, M. (2002). Developing professional knowledge and competence. Routledge.

European Commission. (2019, 8. července). Key competences for lifelong learning. https://op.europa. eu/en/publication-detail/-/publication/297a33c8-a1f3-11e9-9d01-01aa75ed71a1/language-en

Eurydice. (2002). Key Competencies. A developing concept in general compulsory education. http://www. edmide.gr/KEIMENA\%20E.U/key\%20competences\%20Europe.pdf

Fidrmuc, J. (2018, 13. prosince). Reviz̨e RVP všeobecně vądèlávacich prédmètů [Př́spěvek prezentovaný na konferenci]. Konstruktivistické př́stupy ve vzdělávání v perspektivě (nejen) oborových didaktik, Brno, Česká republika.

Ford, M. E. (1992). Motivating humans: Goals, emotions, and personal agency beliefs. Sage.

Gonczi, A. (1994). Competency based assessment in the professions in Australia. Assessment in Education: Principles, Policy \& Practice, 1(1), 27-44. https://doi.org/10.1080/0969594940010103

Gordon, J., Halász, G., Krawczyk, M., Leney, T., Michel, A., Pepper, D., Putkiewicz, E., \& Wiśniewski, J. (2009). Key competences in Europe: Opening doors for lifelong learners across the school curriculum and teacher education. CASE.

Harris, B. (2001). Are all key competencies measurable? An education perspective. In D. S. Rychen \& L. H. Salganik (Eds.), Defining and selecting key competencies (pp. 222-227). Hogrefe \& Huber.

Hartig, J., Klieme, E., \& Leutner, D. (Eds.). (2008). Assessment of competencies in educational contexts. Hogrefe.

Helmke, A. (2009). Unterrichtsqualität und Lehrerprofessionalität: Diagnose, Evaluation und Verbesserung des Unterrichts. Klett. 
Hodge, S. (2007). The origins of competency-based training. Australian Journal of Adult Learning, 47(2), 79-209.

Hodkinson, P. (1992). Alternative models of competence in vocational education and training. Journal of Further and HigherEducation, 16(2), 30-39. https://doi.org/10.1080/0309877920160204

Hučínová, L. (2004, 29. června). Klícové kompetence: nová výzva z EU II. Metodický portál RVP. cz. https://clanky.rvp.cz/clanek/c/ZVN/13/KLICOVE-KOMPETENCE---NOVAVYZVA-Z-EU-II.html/

Hučínová, L. (2005, 22. řína). Kličové kompetence: nová výzva z EU I. Metodický portál RVP.cz. https://clanky.rvp.cz/clanek/c/ZVN/10/KLICOVE-KOMPETENCE---NOVA-VYZVAZ-EU-I.html/

Hutmacher, W. (1996, 30. března). Key competencies for Europe [Report of the Symposium]. Council for Cultural Co-operation (CDCC), A secondary education for Europe, Berne, Switzerland. https://files.eric.ed.gov/fulltext/ED407717.pdf

Chytrý, V., Medová, J., Říčan, J., \& Škoda, J. (2020). Relation between pupils' mathematical self-efficacy and mathematical problem solving in the context of the teachers' preferred pedagogies. Sustainability, 12(23), 1-22. https://doi.org/10.3390/su122310215

Janík, T., Slavík, J., Najvar, P., Hajdušková, L., Hesová, A., Lukavský J., Minaříková, E., Píšová, M., \& Švecová, Z. (2011). Kurikulární reforma na gymnáziich: od virtuálnich hospitací k videostudiím. Výzkumná zpráva NÚV.

Janík, T., Slavík, J., Mužík, V., Trna, J., Janko, T., Lokajíčková, V., Lukavský, J., Minař́íková, E., Sliacky, J., Šalamounová, Z., Šebestová, S., Vondrová, N., \& Zlatníček, P. (2013). Kvalita (ve) vzdèláváni: obsahově zaměrený prístup ke zkoumáni a zlepšováni výuky. Masarykova univerzita.

Jarníková, J., \& Tupý, J. (2011). Výr žum kvality výnky prostrednictvím hospitací. NÚV, divize VÚP.

Kaščák, O., \& Pupala, B. (2009). Výchova a vadelávanie v základnj́ch diskurzoch. Rokus.

Kaščák, O., \& Pupala, B. (2012). Škola zllatých golierov: vzdelávanie v ére neoliberalizmu. Slon.

Klieme, E., Hartig, J., \& Rauch, D. (2008). The concept of competence in educational contexts. In J. Hartig, E. Klieme, \& D. Leutner (Eds.), Assessment of competencies in educational contexts (pp. 3-22). Hogrefe.

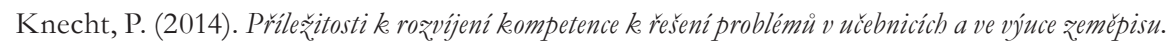
Munipress.

Knecht, P, Janík, T., Najvar, P., Najvarová, V., \& Vlčková, K. (2010). Př́ležitosti k rozvíjení kompetence k řešení problémů ve výuce na základních školách. Orbis Scholae, 4(3), 37-62. https://doi.org/10.14712/23363177.2018.110

Kofroňová, O. (1998). Transformace kurikula v rámci projektu PHARE „Reforma odborného vzdělávání“. Pedagogika, 48(4), 371-379.

Koncepce rè̌eníproblémových úloh ve výžumu PIS A 2003. (2003). Ústav pro informace ve vzdělávání. https://www.csicr.cz/getattachment/cz/O-nas/Mezinarodni-setreni-archiv/PISA/PISA2003/Koncepce-reseni-problemovych-uloh-publikace.pdf

Lokajíčková, V. (2013). Kompetence k učení a možnosti jejího rozvíjení a hodnocení: vymezení pojmu a přehled současných př́stupů. Pedagogická orientace, 23(3), 318-341. https://doi. org/10.5817/PedOr2013-3-318

Lokajíčková, V. (2014). Kvantitativní analýza výukových situací z pohledu rozvíjení kompetence $\mathrm{k}$ učení ve výuce zeměpisu: vybrané výsledky výzkumu. In T. Janík, J. Slavík, V. Lokajíčková, A. Bendová, K. Gažová, M. Horáčková, I. Janoušková, L. Pavlíčková, K. Ševčíková, J. Vlčková, \& L. Ziembová, Školni vżděláváni: Učitel-vyučování, žák - učeni (s. 93-120). Masarykova univerzita. 
Manley, K., \& Garbett, R. (2000). Paying Peter and Paul: R concepts of expertise with competency for a clinical career structure. Journal of Clinical Nursing, 9(3), 347-359. https:// doi.org/10.1046/j.1365-2702.2000.00408.x

McClelland, D. C. (1973). Testing for competence rather than for "intelligence". American Psychologist, 28(1), 1-14. https://doi.org/10.1037/h0034092

McMullan, M., Endacott, R., Gray, M. A., Jasper, M., Miller, C. M., Scholes, J., \& Webb, C. (2003). Portfolios and assessment of competence: A review of the literature. Journal of Advanced Nursing, 41(3), 283-294. https://doi.org/10.1046/j.1365-2648.2003.02528.x

Mertens, D. (1974). Schlüsselqualifikationen Thesen zur Schulung für eine moderne Gesellschaft. Mitteilungen aus der Arbeitsmarkt und Berufsforschung, 7, 36-43.

MŠMT. (2001). Národni program rozvoje vąèláváni v České republice: Bílá kniha. Tauris.

MŠMT. (1999, květen). Koncepce vadèláváni a rozvoje vąělávaci soustavy v České republice. https:// www.vlada.cz/cz/clenove-vlady/historie-minulych-vlad/!-koncepce-vzdelavania-rozvojevzdelavaci-soustavy-v-cr-2094/

Morcke, A. M., Dornan, T., \& Eika, B. (2013). Outcome (competency) based education: An exploration of its origins, theoretical basis, and empirical evidence. Advances in Health Sciences Education, 18(4), 851-863. https://doi.org/ 10.1007/s10459-012-9405-9

Národní ústav odborného vzdělávání [NÚOV]. (n.d.). K vývoji konceptu kličových kompetencí. http://www.nuov.cz/k-vyvoji-konceptu-kk\#article

Norris, N. (1991). The trouble with competence. Cambridge Journal of Education, 21(3), 331-341. https://doi.org/10.1080/0305764910210307

Papáček, M. (2010). Badatelsky orientované prŕírodovědné vyučování cesta pro biologické vzdělávání generací Y, Z a alfa? Scientia in Educatione, 1(1), 33-49. https://doi.org/10.14712/ 18047106.4

PISA. (2003). The PIS A 2003 assessment framework - mathematics, reading, science and problem solving knowledge and skills. OECD.

PIS A 2012: Koncepóní rámec pro zjištováni schopnosti résit problémy. (2012). Česká školní inspekce. http://www.csicr.cz/html/PISA-KoncepRamec/html5/index.html?\&locale=CSY\&pn=1

PISA. (2017). PIS A 2015: Assessment and analytical framework: Science, reading, mathematic, financial literacy and collaborative problem solving. OECD.

Proposal for a council recommendation on key competences for lifelong learning. (2018). http://data. consilium.europa.eu/doc/document/ST-5464-2018-ADD-2/EN/pdf

Rámcový vądèlávaci program pro základni vądèlávání. (2005). NÚV.

Rámcový vądèlávaci program pro základni vždèlávání. (2021). MŠMT.

Recommendation of the European Parliament and of the Council on key competences for lifelong learning. (2006, 18. prosince). Official Journal of the European Union, 394, 10-18. https://eur-lex.europa.eu/LexUriServ/LexUriServ.do?uri=OJ:L:2006:394:0010:0018: en:PDF

Roth, H. (1971). Pädagogische Anthropologie. Schroedel.

Rychen, D. S. (2001). Introduction. In D. S. Rychen \& L. H. Salganik (Eds.), Defining and selecting key competencies (pp. 1-16). Hogrefe \& Huber Publishers.

Rychen, D. S., \& Salganik, L. H. (Eds.). (2001). Defining and selecting key competencies. Hogrefe \& Huber Publishers.

Sadler, D. R. (2013). Making competent judgments of competence. In S. Blömeke, O. ZlatkinTroitschanskaia, Ch. Kuhn, \& J. Fege (Eds.), Modeling and measuring competencies in higher education (pp. 11-27). Sense Publishers. 
Sekundárni analýzy výsledkư šetrené PIS A 2012 - řésení problémů. (2014). Česká školní inspekce. http://www.csicr.cz/html/Sekundarni_reseni_problemu/html5/index.html?\&locale= CSY\&pn=1

Shavelson, R. J. (2010). On the measurement of competency. Empirical research in vocational education and training, 2(1), 41-63. https://doi.org/10.1007/BF03546488

Skalková, J. (2005). Rámcové vzdělávací programy - dlouhodobý úkol. Pedagogika, 55(1), 4-19.

Slavík, J., Janík, T., Najvar, P., \& Knecht, P. (2017). Transdisciplinárni didaktika: o učitelském sdíleni znalosti a zyysováni kvality výnky napríc obory. Masarykova univerzita.

Strategický rámec Česká republika 2030. Vz̃dělávání. (2017). Úřad vlády ČR. https://www.cr2030. cz/strategie/kapitoly-strategie/lide-a-spolecnost/1-4-vzdelavani/

Štech, S. (2009). Zřetel k učivu a problém dvou modelů kurikula. Pedagogika, 59(2), 105-115.

Štech, S. (2013). Když je kurikulární reforma evidence-less. Pedagogická orientace, 23(5), 615-633. http://dx.doi.org/10.5817/PedOr2013-5-615

The definition and selection of key competencies: Executive summary. (2005). Dostupné $\mathrm{z}$ https://www. deseco.ch/bfs/deseco/en/index/02.parsys.43469.downloadList.2296.DownloadFile. tmp/2005.dskcexecutivesummary.en.pdf

Tupý, J. (2018). Tvorba kurikulárnich dokumentio v České republice. Historicko-analytický pobled na prípravu kurikulárnich dokumentů pro základni vadèláváni v letech 1989-2017. Munipress.

Veteška, J., \& Tureckiová, M. (2008). Kompetence ve vždělávání. Grada Publishing.

Weinert, F. E. (2001). Concept of competence: A conceptual clarification. In D. S. Rychen \& L. H. Salganik (Eds.), Defining and selecting key competencies (pp. 45-66). Hogrefe \& Huber.

Westera, W. (2001). Competences in education: A confusion of tongues. Journal of Curriculum Studies, 33(1), 75-88. https://doi.org/10.1080/00220270120625

Willbergh, I. (2015). The problems of 'competence'and alternatives from the Scandinavian perspective of Bildung. Journal of Curriculum Studies, 47(3), 334-354. https://doi.org/10.10 80/00220272.2014.1002112

\section{Kontakt na autorku}

Tereza Češková

Institut výzkumu školního vzdělávání, Pedagogická fakulta, Masarykova univerzita

E-mail: ceskova@ped.muni.cz

\section{Corresponding author}

Tereza Češková

Institute for Research in School Education, Faculty of Education, Masaryk Univesity

E-mail: ceskova@ped.muni.cz 
